Науковий вісник НлТУ України

Scientific Bulletin of UNFU

https://nv.nltu.edu.ua

https://doi.org/10.36930/40290825

Article received $24.09 .2019 \mathrm{p}$.

Article accepted 31.10.2019 p.

удК 65.012:69.004:338.24
ISSN 1994-7836 (print)

ISSN 2519-2477 (online)

$@ \bowtie$ Correspondence author

A. I. Ivanusa

ivaaanusa@gmail.com

А. І. Івануса ${ }^{1}$, Р. С. Яковчук ${ }^{1}$, С. О. Ємельяненко ${ }^{1}$, 3. З. Івануса ${ }^{2}$

${ }^{I}$ Львівський державний університет безпеки життєдіяльності, м. Львів, Украӥна

2 Львівський державний університет внутрішніх справ, м. Львів, Украӥна

\title{
УПРАВЛІНСЬКІ ТА ІНФОРМАЦІЙНІ ОСОБЛИВОСТІ ПРОЕКТУ БЕЗПЕЧНОЇ ЕКСПЛУАТАЦІЇ СПОРТИВНО-ВИДОВИЩНИХ СПОРУД
}

\begin{abstract}
Здійснено інформаційний аналіз предметної галузі безпеки життєдіяльності на об'єктах масового перебування людей, який засвідчив, що основним способом їх убезпечення на спортивно-видовищних спорудах є створення умов для проведення своєчасної та безперешкодної евакуації людей у безпечну зону. Аналіз сучасного стану реалізації проектів безпечної експлуатації спортивно-видовищних споруд (БЕ СВС) у процесі вживання спортивних та культурно-масових заходів засвідчив, що: існує невідповідність вимогам чинного українського законодавства світовим у плані убезпечення людей, а також немає нормативно-правової бази та "Правил поведінки", які б визначали порядок реалізації проектів у сфері убезпечення людей на спорудах масового їх перебування під час вживання масового заходу. Розроблено теоретичні засади, які базуються на основі топологічного аналізу та синтезу систем управління потоками людей, що $є$ зацікавленими сторонами проектів БЕ СВС. В основу інструментальних засобів щодо реалізації таких проектів покладено формалізацію методів і моделей, які інформують про стан їх поточної реалізації. Розроблено концептуальну модель управління проектами БЕ СВС, кінцевим результатом якої є збережене життя та здоров'я зацікавлених сторін проектів. Встановлено, що для проведення розрахунку тривалості евакуації зацікавлених сторін проектів БЕ СВС із секторів на променаду найбільш оптимальним $€$ використання аналітичної моделі, що враховує топологію руху людського потоку, а з променади в безпечну зону - моделі індивідуальнопотокового руху людини в складі потоку, яка показана у вигляді модифікованої функції Ерланга.
\end{abstract}

Ключові слова: безпека життєдіяльності; евакуація людей; безпеко-орієнтоване управління проектами; спортивно-видовищні споруди.

Вступ. Підвищення ефективності реалізації програми створення та розвитку системи безпеки на об'єктах (спорудах) масового перебування людей потребує використання методів та моделей, що побудовані на основі використання інформаційних технологій, системного підходу та проектно-орієнтованого управління. Оскільки споруди цього типу за класифікацією поділяються на категорії, відповідно до яких там можуть вживатися спортивні, культурно-масові та інші заходи різного рівня значущості, то існують й різні вимоги щодо параметральних та інших характеристик, які враховуються на стадії проектування, функціонування, розвитку.

Дослідження етапу ефективного функціонування об'єктів, що входять у систему спортивно-видовищного типу, можливо за умов дослідження наявних механізмів та програм їх розвитку, а також у визначенні кращих світових практик реалізації проектів безпечної експлуатації спортивно-видовищних споруд (БЕ СВС). До та- ких об'єктів можна віднести: торгово-розважальні заклади, спортивно-видовищні споруди, аеропорти, вокзали, театри тощо.

Розробленню науково-методичних засад управління часом та користувачами проектів значну увагу приділили у своїх роботах С. Д. Бушуєв, та В. А. Рач та ін. У своїх роботах вони запропонували методологічні засади, принципи, методи, моделі ризик-орієнтованого підходу, які забезпечують вирішення питань щодо управління ризиками, ресурсами, фінансами, часом та якістю проектів і програм (Bushuiev, 2010; Rach, 2010).

Професор С. К. Чернов у своїй праці (Chernov, 2006) запропонував механізм формування портфелю проектів забезпечення енергетичної безпеки на об'єктах критичної інфраструктури, що є основою для подальших досліджень у напрямі управління проектними ризиками.

Розробку нових та вдосконалення наявних методів, моделей та механізмів управління рятувальними служ-

Інформація про авторів:

Івануса Андрій Іванович, канд. техн. наук, доцент, кафедра права та менеджменту у сфері цивільного захисту.

Email: ivaaanusa@gmail.com; https://orcid.org/0000-0001-9141-8039

Яковчук Роман Святославович, канд. техн. наук, докторант, кафедра права та менеджменту у сфері цивільного захисту. Email: juniorrs@i.ua; https://orcid.org/0000-0001-5523-5569

Ємельяненко Сергій Олександрович, канд. техн. наук, начальник відділу організації науково-дослідної роботи. Email: serg007e@gmail.com; https://orcid.org/0000-0002-2766-8428

Івануса Зоряна Зенонівна, канд. юрид. наук, ст. наук. співробітник, відділ наукової роботи. Email: zoryana_pz@ukr.net

Цитування за ДСтУ: Івануса А. І., Яковчук Р. С., Ємельяненко С. О., Івануса 3. 3. Управлінські та інформаційні особливості проекту безпечної експлуатації спортивно-видовищних споруд. Науковий вісник НлтУ України. 2019, т. 29, № 8. С. 134-141.

Citation APA: Ivanusa, A. I., Yakovchuk, R. S., Yemelyanenko, S. O., \& Ivanusa, Z. Z. (2019). Some management and information aspects of the project of safety operation of sports and entertainment buildings. Scientific Bulletin of UNFU, 29(8), 134-141.

https://doi.org/10.36930/40290825 
бами та системою цивільного захисту розглянуто в роботах (Rak, 2013; Zachko, 2017). У цих працях наведено способи рішення науково-прикладної проблеми щодо побудови методологічних основ безпеко-орієнтованого управління проектами розвитку складних організаційно-технічних систем на прикладі цивільного захисту. Автори роботи запропонували системну модель безпеки проекту будівництва спортивно-видовищних споруд, яка реалізує методологічні підходи до планування безпеки на концептуальній стадії життєвого циклу проекту. Запропонували підхід до розроблення моделей життєвого циклу продукту проекту розвитку інфраструктури складної регіональної системи, який передбачає формалізацію всіх основних процесів системи.

Хоча науково-технічний прогрес набув великих масштабів, проте питання щодо безпеки людини на СВC залишається і надалі актуальним, про що свідчать трагедії, які часто виникають на об'єктах цього типу в процесі їх експлуатації. Одним із можливих напрямів вирішення завдання щодо підвищення безпеки людей у проектах БЕ СВС є проведення та впровадження сучасних інформаційних технологій в практику наукових досліджень 3 методології управління проектами в умовах надзвичайних ситуацій (НC), а також управління користувачами та часом реалізації проектів.

Об'єкт дослідження - процеси управління часом та користувачами проекту безпечної експлуатації спортивно-видовищних споруд.

Предмет дослідження - моделі та методи управління часом та користувачами проекту безпечної експлуатації CBC.

Метою дослідження є розроблення робочого інструментарію реалізації проекту безпечної експлуатації спортивно-видовищних споруд. Досягнення поставленої мети зумовило потреба вирішення таких завдань:

1) проаналізувати предметну галузь, а саме проекти безпечної експлуатації спортивно-видовищних споруд;

2) проаналізувати сучасні моделі та методи управління проектами безпечної експлуатації спортивно-видовищних споруд, а саме в частині управління часом та управління користувачами (зацікавленими сторонами) проекту в умовах виникнення надзвичайної ситуації;

3) розробити моделі, методи та програмний продукт управління користувачами та часом в проектах безпечної експлуатації об'єктів масового перебування людей.

Результати дослідження та їх обговорення. Небезпека для людей під час перебування на спортивно-видовищних спорудах полягає в тому, що їх велике скупчення може спричинити тисняву на окремих іiі ділянках, підвищується імовірність вчинення терористичного акту, можливе обвалення конструкцій, виникнення масових безпорядків, пожежі чи надзвичайної ситуації та ін., що становить загрозу життю та здоров'ю людини. Проте не завжди зазначенні вище джерела небезпек стаються на СВС. Під час організації масових спортивних та культурно-видовищних заходів різних масштабів виникають різні джерела небезпек, яким необхідно протидіяти. Тому з метою раціонального використання ресурсів у проектах БЕ СВС, під час організації та вживання масових заходів, їх поділяють на певні рівні значущості. Згідно з "Положенням про порядок підготовки спортивних споруд та інших спеціально відведених місць для проведення масових спортивних та культурно-видовищних заходів", події за своїм значенням поді- ляють на міжнародні, державні та регіональні (DBN V 2.2-9-09, 2010).

Якщо ж масові заходи регіонального та державного значень можна вживати відповідно до чинної української нормативно-правової бази, то міжнародні - відповідно до української і світової. Враховуючи цю особливість, відразу помітно в чому полягає успіх реалізації проектів БЕ СВС - приведення однієї нормативно-правової бази у відповідність до іншої, оскільки така неузгодженість може призвести до нераціонального використання ресурсів, знизити рівень якості продукту проекту чи поставити під загрозу саму реалізацію такого проекту.

Чинна законодавча база України, що регламентує вимоги стосовно забезпечення безпеки на СВС під час організації та вживання спортивних та культурно-масових заходів різного рівня значущості, представлена у DBN V 2.2-13-2003, 2004; Zakon Ukrainy № 3673-VI, 2011; nakaz MNS Ukrainy №1243, 2012; HOST 12.1.00491,1991 , вона доповняє або уточнює певні вимоги, а інколи і дублює. Європейські вимоги в цьому напрямі представлені у (The control of crowds at football matches, 1991; Guide to Safety at Sports Grounds, 1997; Stadium Infrastructure Regulations, 2006) і є узгодженні з нормативними актами країн-членів Європейського Союзу.

Невідповідність нормативно-правової бази України в галузі будівництва СВС рекомендаціям УЄФА широко обговорювали на численних засіданнях, конференціях, круглих столах на різних рівнях управління нашою державою із представниками УЄФА в період підготовки України та Польщі до проведення чемпіонату Свропи 3 футболу 2012 р. (Свро-2012). Як результат, в Україні було додатково розроблено та задіяно законодавчі акти, які вдосконалюють чинну українську нормативноправову базу та приводять у відповідність до європейської.

Одними $з$ таких законодавчих актів, які потребували змін та доповнень, є Закон України "Про особливості забезпечення громадського порядку та громадської безпеки у зв'язку з підготовкою та проведенням футбольних матчів" № 3673-VI від 08 липня 2011 р. та Кодекс України про адміністративні правопорушення.

Як показав досвід проведення чемпіонату України 3 футболу серед команд клубів Професійної футбольної ліги, проблема полягає в тому, що особи, які залучаються клубами до забезпечення громадського порядку та безпеки на території спортивної споруди, не мають визначених законодавством необхідних повноважень (наприклад, проведення огляду особистих речей глядачів), а також не можуть зупиняти випадки насильницьких дій та неналежної поведінки організованих груп футбольних хуліганів. Варто також зазначити, що розділ 3 Закону (Zakon Ukrainy № 3673-VI, 2011) "Відповідальність за порушення вимог законодавства про забезпечення громадського порядку та громадської безпеки у зв'язку 3 підготовкою та проведенням футбольних матчів" не враховує норми регламентних документів УЄФА та ФФУ в частині дисциплінарної відповідальності організаторів футбольних матчів.

Отже, під час проведення змагань державного рівня постала потреба у перегляді деяких норм з метою встановлення i, особливо, розмежування обов'язків та повноважень як організаторів, так і спеціальних підрозділів правоохоронних органів, а також взяти до уваги норми регламентних документів УЄФА та ФФУ в частині дис- 
циплінарної відповідальності за порушення вимог законодавства щодо забезпечення громадського порядку та громадської безпеки під час підготовки та проведення футбольних матчів.

Також необхідно встановити відповідальність осіб, які порушують правила поведінки, громадський порядок та можуть своїми діями завдати шкоди безпеці громадян, які перебувають на території спортивної споруди, де відбувається культурно-масовий захід. Цю норму мав би регламентувати Кодекс України про адміністративні порушення. Проте Положення цього Кодексу сьогодні взагалі не містять виду, переліку порушень громадського порядку і громадської безпеки та не передбачають відповідальності за такі правопорушення до, під час та після вживання масових заходів.

Тому в Україні і було розроблено Проект Закону, який передбачав внесення змін та доповнень до Закону України "Про особливості забезпечення громадського порядку та громадської безпеки у зв'язку з підготовкою та проведенням футбольних матчів" та Кодексу України про адміністративні правопорушення у частині забезпечення громадського порядку та громадської безпеки до, під час та після вживання спортивних та культурно-масових заходів.

Проведення спортивних та культурно-масових змагань європейського рівня у різних країнах, а особливо у тих країнах, де великомасштабні заходи міжнародного значення відбуваються вперше, потребує реалізації проектів побудови нових або реконструкції старих СВС відповідно до світових стандартів. Проект будівництва чи реконструкції СВС для організації змагань міжнародного рівня потребує перегляду багатьох нормативних актів, якими керуються на стадіях його реалізації, проте в нашому випадку необхідно розглянути ті, що належать до напряму убезпечення людей. Розроблена нормативно-правова база країни-організатора спортивного чи культурно-видовищного заходу безперечно відіграє ключову роль у контексті убезпечення та комфорту на СВС. В європейських країнах вона, як уже зазначалось, представлена у вигляді рекомендацій "Зелена Книга", які діють під егідою УЄФА, а в Україні - у вигляді законів, державних будівельних норм, ГОСТів, правил пожежної безпеки та інших додаткових нормативних актів.

Інформаційний аналіз нормативно-правових баз засвідчив, що найбільш ефективним способом убезпечення відвідувачів СВС є своєчасна та безперешкодна їх евакуація у безпечну зону. Згідно з європейськими вимогами, тривалість проведення такого процесу не повинна перевищувати 8 хв. Водночас, українська законодавча база взагалі не регламентує цю вимогу для СВС напіввідкритого та відкритого типу. Таке часове обмеження було встановлено на основі результатів дослідження і набутого досвіду з експлуатації $\mathrm{CBC}$, який свідчить про те, що в цей період спостерігають низький рівень виникнення загроз життю та здоров'ю людей, а також завдання матеріальної шкоди.

Для збереження умов стану безпеки та комфортності глядачів, які перебувають на об'єктах спортивно-видовищного типу під час проведення міжнародних спортивних змагань, було проаналізовано основні нормативні документи України в галузі будівництва та експлуатації СВС та рекомендації УСФА $з$ метою встановлення чинників впливу на процес евакуації. Інформаційний аналіз визначив чинники, що впливають на ії функціонування, а також показав несумісність вимог, які потребують узгодження, а також ту нормативно-правову базу, чиї вимоги з певних напрямів $є$ вищими та мають бути виконані в процесі реалізації проекту побудови чи реконструкції СВС для проведення культурно-масового заходу міжнародного значення (рис. 1, 2).

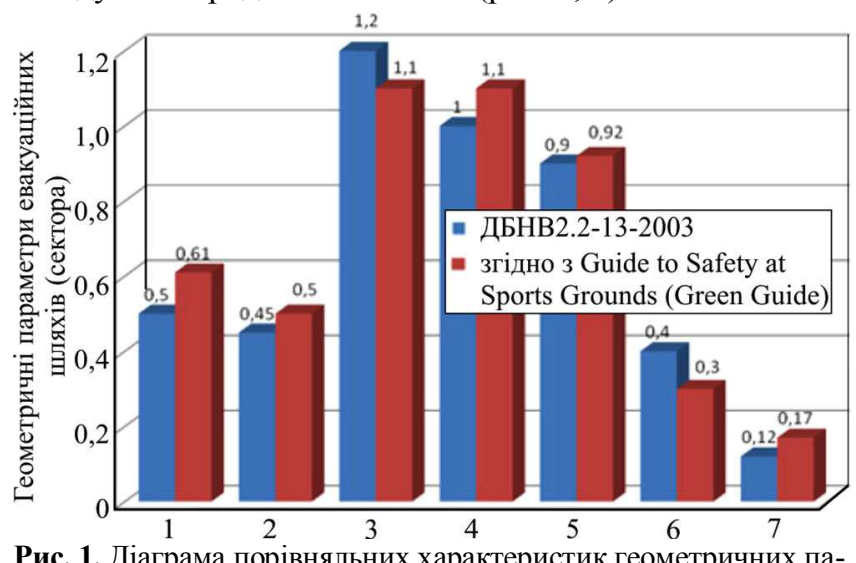

Рис. 1. Діаграма порівняльних характеристик геометричних параметрів проекту створення та розвитку систем спортивно-видовищного типу: 1) ширина проходу між рядами; 2) ширина сидіння; 3 ) висота огорожі (яку варто передбачати на верхніх ярусах трибун); 4) ширина шляхів евакуації горизонтальних проходів, пандусів і сходів; 5) висота поручнів; 6) сходинки (ширина просвіту); 7) сходинки (висота підйому)

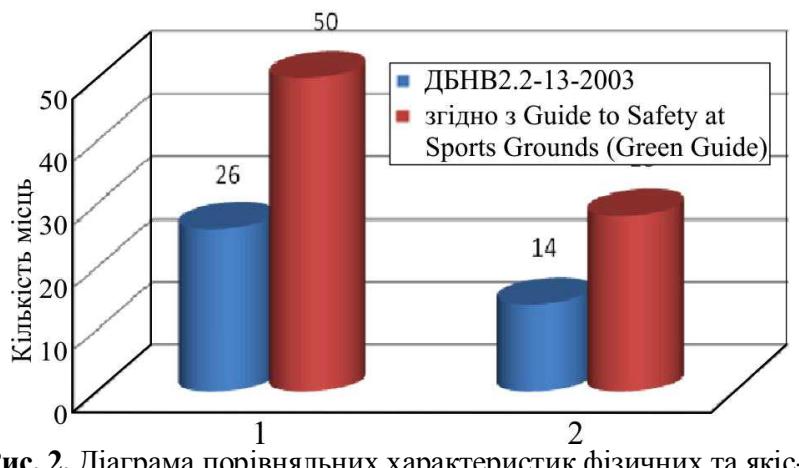

Рис. 2. Діаграма порівняльних характеристик фізичних та якісних параметрів проекту безпечної евакуації глядачів із СВС: 1) кількість місць у ряду (за односторонньої евакуації); 2) кількість місць у ряду (за двосторонньої евакуації)

Зазначені на рисунках параметри характеризують систему евакуації, за якої проходять потоки людей, і є, до певної міри, вихідними даними для проведення обчислень під час розрахунку тривалості евакуації людей iз споруди в безпечну зону.

Перевірка відповідності всіх складових системи безпеки СВС до норм проектування здійснюється способом проведення теоретичного розрахунку тривалості евакуації людей у безпечну зону. Якщо за певних причин, наприклад, за недостатньої кількості виходів, глядачі не можуть покинути споруду протягом регламентованого часу, то може виникнути потреба скоротити загальну місткість споруди, внаслідок чого зменшується ефективність реалізації проекту побудови чи реконструкції СВС, що надалі може призвести до втрати його цінності.

Проведений інформаційний аналіз наукових робіт (Yemelyanenko, 2017; Ivanusa, 2018), методів, методик та нормативно-правової бази країн Свропейського Союзу (СС), які описують рух потоків людей, показав, що в архітектурно-будівельному проектуванні не використовують математичні вирази для визначення розмірів 
евакуаційних шляхів та виходів, а використовують норму - кількість людей на одиницю ширини евакуаційного шляху. Відповідно така модель описує людський потік у вигляді "елементарних" потоків, паралельних рядів людей, що ідуть один за одним. Ця модель показує: наявність залежності між швидкістю i щільністю людського потоку та вплив на неї виду шляху; потреба приймати за основу нормування не пропускну здатність, а тривалість евакуації, що залежить від сукупності чинників руху людського потоку; недоцільність нормування пропускної здатності шляху евакуації без зазначення часу його використання.

На практиці ця модель є значно спрощеною з огляду на те, що значення швидкості руху елементарного людського потоку за видами шляху прийняті мінімальними: горизонтально - $16 \mathrm{M} / \mathrm{xв}$, сходи вниз - $10 \mathrm{M} / \mathrm{xв}$, сходи вверх -8 м/хв. Пропускна здатність елементарного потоку на хвилину також $є$ постійною величиною для будь-якого виду шляху: 25 ос./хв. Ширина елементарного потоку 0,5-0,6 м.

В українській нормативно-правовій базі рух потоків людей у процесі евакуації описано в ГОСТ 12.1.004. У Додатку 2 цього документа зазначено, що загальна тривалість евакуації людей із споруди складається з інтервалу часу від виникнення пожежі чи НС до початку евакуації людей та розрахункового тривалості евакуації, що є сумою тривалостей руху потоку людей окремими ділянками евакуаційного маршруту.

Однією $з$ найпростіших є "Модель руху (без розтікання) людського потоку одноманітного складу". Саме цю модель і використовують у ГОСТ 12.1.004-91 в Додатку 2 "Метод определения уровня обеспечения пожарной безопасности людей". У ній розглянуто евакуацію людей у складі потоків людей і відповідно під час проведення розрахунків з допомогою цієї моделі необхідно оперувати параметрами, які характерні для руху людського потоку. Також вона показує кількість людей та порядок їх евакуації, пройдену ними відстань та тривалість евакуації з певної ділянки приміщення, місце розташування потоку, значення швидкості та часу, затраченого на переформування потоків. За результатами проведених розрахунків на основі моделей цього типу можна встановити геометричні параметри евакуаційних шляхів та виходів для забезпечення безперешкодної та своєчасної евакуації людей із приміщень.

Для побудови моделей руху людських потоків ми, на основі аналізу причинно-наслідкових зв'язків і використання японської системи знань Р2М, початково побудували концептуальну модель управління проектами БЕ СВС, яка враховує: стан турбулентного середовища реалізації проектів спортивно-видовищного характеру, рівень вживання спортивних та культурно-масових заходів, ключові чинники успіху реалізації проектів БЕ CBC, нормативно-правову базу України та рекомендації УЄФА, психофізіологічний стан людей, стратегічні цілі, показники результативності. Схему реалізації такої моделі представлено на рис. 3.

Результатом успішної реалізації проектів БЕ СВС є збережене життя та здоров'я людей під час перебування на споруді, які виступають у ролі користувачів проекту. Моделі управління користувачами проекту відображають евакуаційні маршрути руху потоків людей із споруди в безпечну зону, а також параметри, що вливають на рух людей на окремих евакуаційних ділянках, які пот- рібно враховувати під час проведення розрахунку часу реалізації проектів БЕ СВС.

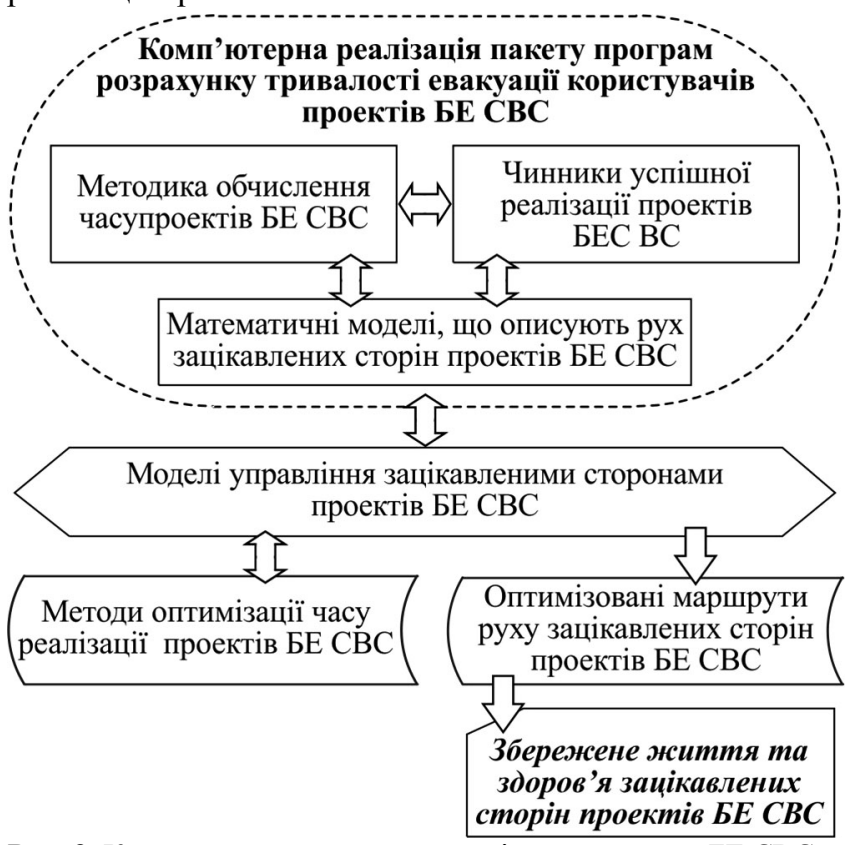

Рис. 3. Концептуальна модель управління проектами БЕ СВС

Використовуючи моделі управління користувачами проектів, наявні математичні моделі, що описують рух потоків людей на спорудах масового їх перебування та орієнтуючись на чинники успішної реалізації проектів БE CBC, можна створити програмний продукт, який забезпечить автоматизацію проведення необхідних розрахунків. Результати розрахунків покажуть спроможність евакуаційної системи забезпечити своєчасну евакуацію людей із споруди в межах регламентованого часу та потреба проведення оптимізації руху потоків користувачів проекту.

Враховуючи, що процес руху користувачів проекту БЕ СВС характеризується такими динамічними параметрами, як: щільність " $D$ ", швидкість " $V$ ", кількість користувачів " $N$ ", геометричні параметри сходів " $M$ ", напрямки руху " $S$ ", архітектуру споруди " $A$ ", довжина евакуаційного маршруту " $L$ ", психологічний стан користувачів "Е" та інформаційне забезпечення користувачів "I" тощо, цільову функцію потоку зацікавлених сторін проектів під час евакуації із споруди в безпечну зону можна показати у вигляді кортежу

$$
F(x)=\langle D, V, N, M, S, A, L, E, I, O, P, H C\rangle,
$$

де: $O$ - природні умови; $P$ - рівень вживання заходу (територіальний, державний, міжнародний); $H C$ - тип надзвичайної ситуації.

Після формалізації предметної галузі, що враховує закони та особливості поведінки людей, під час руху у вигляді потоків людей через евакуаційні шляхи та ще й в умовах НС, отримаємо інтеграційну пірамідальну модель-схему системної динаміки в проектно-орієнтованому управлінні (рис. 4).

У верхній частині піраміди використано інтеграційні моделі та системи управління проектами безпечної евакуації користувачів проекту (MS Project, Primavera, Oracle тощо), здатні забезпечити процесний, сценарний та системний підхід управління складними системами поведінки людей у разі виникнення пожежі чи НС природного або техногенного характеру. Нижній рівень піраміди є сукупністю знань, представлених у виг- 
ляді модулів супервізора та картотеки методів, моделей, інструментів і модуля експертизи для підтримки стану отримання достовірної інформації, правильності відбору технологій, інструментарію тощо, з метою міні- мізації ресурсних витрат та забезпечення найвищої імовірності безпеки під час евакуації потоків людей на період масового заходу.

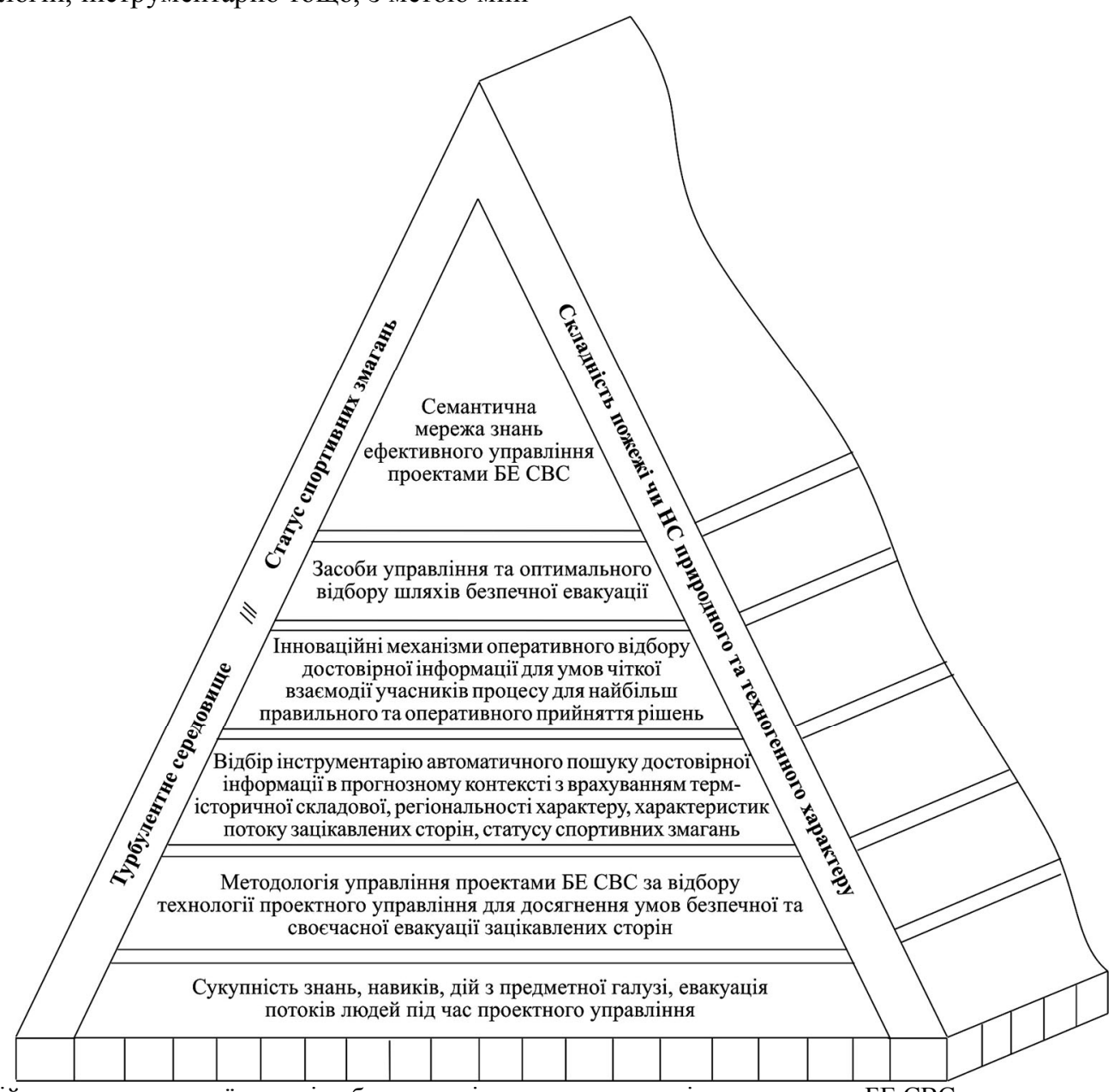

Рис. 4. Інтеграційна схема системної динаміки безпеко-орієнтованого управління проектами БЕ СВС

Таку методологію управління проектами безпечної евакуації потоків людей побудовано за допомогою використання методів критичних шляхів, де оптимізаційний синтез евакуаційного маршруту людей розглядають як топологічну схему технологічної лінії, а сам евакуаційний шлях розділяють на окремі операції (блоки).

Тривалість реалізації проектів БЕ СВС залежить від часу виходу потоків людей в безпечну зону, які виступають у проектах у ролі зацікавлених сторін. Порядок проведення обчислень стосовно визначення загального тривалості евакуації людей із споруд різного типу призначення, як уже зазначалось, наведений в ГОСТ 12.1.004-91 (далі ГОСТ), що є чинним сьогодні в Україні. Проте він не повністю описує динаміку руху людського потоку, тому під час проведення розрахунків необхідно використовувати додатковий математичний апарат, який здатний описати процеси розтікання, об'єднання та переформатування потоків людей. Оскільки потік людей під час руху по СВС має властивість видозмінюватись, то для проведення обчислень доцільно його поділити на ділянки, в яких спостерігаємо однорідність його руху, що спростить процес обчислення.

Проаналізувавши рух потоків людей на СВC із врахуванням їх об'ємно-планувальних рішень, встановлено параметри, що впливають на рух зацікавлених сторін проектів на окремих евакуаційних ділянках та процес його видозміни під час виходу на променаду. Як результат встановлено, що евакуаційний маршрут для проведення обчислень часу руху зацікавлених сторін із споруди в безпечну зону доцільно розбити на такі евакуаційні ділянки:

- вихід людей із сектора верхнього ярусу $C B C$ : бічний прохід у секторі, радіальний прохід, прохід вниз сходами із сектора, прохід променадою, спуск сходовими маршами на вільну територію (безпечну зону);

- вихід людей із сектора нижнього ярусу $C B C$ : бічний прохід у секторі, радіальний прохід у секторі, прохід променадою, спуск сходовими маршами на вільну територію (безпечну зону).

Радіальний прохід - ступінчаста або нахилена доріжка для руху через зону глядацьких місць, яка проходить між виступами тераси чи рядами крісел.

Боковий прохід - горизонтальна доріжка для руху людей через зону глядацьких місць, яка проходить паралельно виступам тераси чи рядам крісел.

Променада - це спеціально зроблений на певній висоті майданчик, який забезпечує оптимальний рух потоків людей по споруді.

Під час визначення часу руху людей ширину та довжину кожної ділянки приймаємо відповідно до проекту чи дійсних значень параметрів наявної споруди. Довжина сходової клітки чи пандуса дорівнює довжині мар- 
шу, а довжина шляху в дверному отворі дорівнює нулю. Якщо проріз у стіні перевищує 0,7 м, то його необхідно розглядати як горизонтальний евакуаційний шлях.

Отже, розбивши евакуаційний маршрут на ділянки 3 однорідним потоком людей, розрахункова тривалість загальної евакуації зацікавлених сторін проектів $t_{\mathrm{eB}}^{3 \mathrm{ar}}$ iз CBC у безпечну зону визначатимемо як

$$
t_{\mathrm{eB}}^{3 \mathrm{ar}}=t_{\mathrm{eB}}^{\mathrm{c}}+t_{n p},
$$

де: $t_{\mathrm{e}}^{\mathrm{c}}$ - тривалість евакуації зацікавлених сторін проектів із секторів на променаду; $t_{\text {пр }}$ - тривалість евакуації зацікавлених сторін проектів із променади в безпечну зону.

Розрахунок часу виходу зацікавлених сторін проектів із секторів СВС на променаду доцільно проводити за спрощеною аналітичною моделлю руху людського потоку, що наведена в "Методике определения расчетных величин пожарного риска в зданиях, сооружениях и строениях различных классов функциональной пожарной опасности" (Order of the Min. of Emerg. Situat. of Russia, 2009). Враховуючи те, що евакуаційний маршрут поділений на деякі елементарні ділянки, тривалість $t_{\mathrm{e}}^{\mathrm{c}}$ виходу зацікавлених сторін проектів із секторів на променаду визначатиметься як

$$
t_{\mathrm{eB}}^{\mathrm{c}}=\frac{l_{1}}{V_{1}}+\frac{l_{2}}{V_{2}}+\ldots+\frac{l_{n}}{V_{n}}=\sum_{i=1}^{n} \frac{l_{i}}{V_{i}},
$$

де: $l_{i}$ - довжина $i$-ї ділянки евакуаційного шляху; $V_{i}-$ значення швидкості руху зацікавлених сторін проектів на $i$-й ділянці евакуаційного шляху.

Зазначену вище методику розробили російські вчені на заміну ГОСТ 12.1.004-91 з метою вдосконалення опису руху потоків людей на об'єктах різного роду призначення, а використовувана нами аналітична модель передбачає врахування часу можливої затримки руху зацікавлених сторін $t^{\text {c.з.p. }}$ і визначається як

$$
t^{\text {c.3.p. }}=N_{i} \cdot f\left(\frac{1}{q_{n p u D=0,9} \cdot \delta_{i+1}}-\frac{1}{q_{i} \cdot \delta_{i}}\right),
$$

де: $N_{i}-$ кількість зацікавлених сторін на початковій ділянці шляху, ос.; $f$ - площа горизонтальної проекції людини (згідно з "Зеленою Книгою", необхідно приймати $\left.0,25 \mathrm{~m}^{2} / \mathrm{M}^{2}\right) ; \delta_{i}$ - ширина $i$-ї ділянки евакуаційного шляху, м; $q_{i}-$ інтенсивність руху потоків зацікавлених сторін проектів на $i$-й ділянці евакуаційного шляху, м/хв; $D_{i}$ - щільність руху зацікавлених сторін проектів на $i$-й ділянці евакуаційного шляху, ос./ $\mathrm{m}^{2}$.

Проаналізувавши видозмінений потік людей на променаді та визначивши його характеристики, було встановлено, що розрахунок тривалості евакуації зацікавлених сторін проектів БЕ СВС із променади в безпечну зону доцільно проводити за допомогою використання моделі індивідуально-потокового руху людини, що наведена в (Holshevnikov, 2009) як модифікована функція Ерланга

$$
t_{n p}=\frac{1}{t^{2} \cdot S_{V} \cdot \sqrt{2 \pi}} \operatorname{Exp}\left(-\frac{1}{2 S_{V}^{2}}\left(\frac{1}{t_{\text {л.n. }}}-\bar{V}_{n p}\right)^{2}\right),
$$

де: $S_{V}-$ дисперсія випадкової величини, що визначається за формулою

$$
S_{V}^{2}=S_{V_{0}}^{2}\left(1-\alpha_{i} \ln \frac{D_{i}}{D_{0 i}}\right)^{2},
$$

$t_{\text {л.n. }}$ - інтервал часу, що описує зміну розташування людини в потоці; $\bar{V}_{n p}$ - швидкість руху зацікавлених сторін проектів по променаді, що визначається як

$$
\bar{V}_{n p}=\bar{V}_{0 i}^{E}\left(1-\alpha_{i} \ln \frac{D_{i}}{D_{0 i}}\right),
$$

де: $\bar{V}_{0 i}^{E}$ - випадкова величина швидкості вільного руху, що залежить від виду шляху $j$ та рівня емоційного стану Е людини; $\alpha_{i}$ - коефіцієнт, який визначає ступінь впливу щільності потоку зацікавлених сторін під час руху по $i$-й ділянці евакуаційного шляху; $D_{0 i}-$ порогове значення щільності потоку зацікавлених сторін, під час досягнення якого щільність перетворюється у чинник, який впливає на швидкість руху.

Значення $\bar{V}_{0 i}^{E}, \alpha_{i}, D_{0 i}$ - загальновідомі дані, визначені внаслідок багатократних натуральних спостережень (Holshevnikov, 2009).

Отже, загальна тривалість реалізації проектів БЕ CBC у безпечну зону буде визначатись як

$$
t_{\mathrm{eB}}^{\text {заг }}=\sum_{i=1}^{n} \frac{l_{i}}{V_{i}}+\frac{1}{t^{2} \cdot S_{V} \cdot \sqrt{2 \pi}} \operatorname{Exp}\left(-\frac{1}{2 S_{V}^{2}}\left(\frac{1}{t_{\text {r.n. }}}-\bar{V}_{n p}\right)^{2}\right) .
$$

У випадку, коли на евакуаційному маршруті зацікавлених сторін проектів під час виходу із секторів на променаду із певних причин спостерігатиметься затримка руху, то загальна тривалість реалізації проектів БЕ СВС визначатиметься відповідно до залежності

$$
\begin{aligned}
t_{\mathrm{eB}}^{\mathrm{ar}} & =\sum_{i=1}^{n}\left(\frac{l_{i}}{V_{i}}+N_{i} \cdot f\left(\frac{1}{q_{D=0,9} \cdot \delta_{i+1}}-\frac{1}{q_{i} \cdot \delta_{i}}\right)\right)+ \\
+ & \frac{1}{t^{2} \cdot S_{V} \cdot \sqrt{2 \pi}} \operatorname{Exp}\left(-\frac{1}{2 S_{V}^{2}}\left(\frac{1}{t_{\text {ת.n. }}}-\bar{V}_{n p}\right)^{2}\right) .
\end{aligned}
$$

Початкові дані для проведення обчислень наведено в табл. 1.

У процесі виконання обчислень, які проводились за наведеною вище методикою та вихідними даними на прикладі стадіону "Арена Львів", після проведення оптимізації руху людських потоків встановлено:

- сумарна тривалість евакуації зацікавлених сторін проектів із найбільш заповненого сектора верхнього ярусу СВС "Арена Львів", у безпечну зону

$$
T_{e b .}{ }^{1}=390 \mathrm{c.}=6,5 \mathrm{xB}
$$

- сумарна тривалість евакуації зацікавлених сторін проектів iз найбільш заповненого сектора нижнього ярусу СВС "Арена Львів" у безпечну зону

$$
T_{e в .}{ }^{2}=474 \text { с. }=7,9 \text { хв. }
$$

Як уже зазначалось у роботі, світова практика експлуатації СВС засвідчила, що убезпечення відвідувачів та обслуговуючого персоналу на спорудах цього типу досягається шляхом організації та проведення своєчасної евакуації людей у безпечну зону протягом 8 хв. Після чого небезпека завдання шкоди здоров'ю людини та її загибелі значно збільшується. Згідно з проведеним розрахунком, евакуація користувачів стадіону "Арена Львів" із найбільш завантаженого сектору трибуни (найгірший сценарій розвитку події) здійснюється у межах до 8 хв, що відповідає світовим вимогам. Варто відзначити, що досягнення такого показника було мож- 
ливим лише після проведення оптимізації руху людських потоків по споруді та виконанні розроблених прак- тичних рекомендацій стосовно експлуатації стадіону, які наведено в практичній частині роботи.

Табл. 1. Початкові дані для проведення розрахунку часу безпечної експлуатації стадіону "Арена Львів"

\begin{tabular}{|c|c|c|c|c|}
\hline \multirow{16}{*}{ 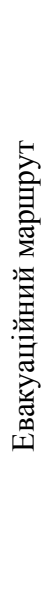 } & \multicolumn{2}{|c|}{ Назва ділянки евакуаційного маршруту } & Параметри евакуаційного маршруту & Фактичне значення \\
\hline & \multirow{9}{*}{ 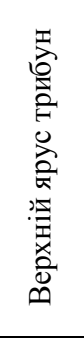 } & \multirow{3}{*}{ прохід у ряді крісел } & ширина проходу в ряді між кріслами, м & 0,4 \\
\hline & & & кількість людей у ряді, ос. & 28 \\
\hline & & & довжина евакуаційного маршруту, м & 15,5 \\
\hline & & \multirow{3}{*}{$\begin{array}{l}\text { радіальний прохід у секторі між ря- } \\
\text { дами крісел }\end{array}$} & ширина радіального проходу в секторі, м & 1,2 \\
\hline & & & кількість людей в потоці, ос. & 786 \\
\hline & & & довжина евакуаційного маршруту, м & 18 \\
\hline & & \multirow{3}{*}{ вихід із сектору на променаду } & ширина виходу з сектору, м & 2,4 \\
\hline & & & кількість людей в потоці, ос. & 786 \\
\hline & & & довжина проходу людей, м & 20 \\
\hline & \multirow{6}{*}{ 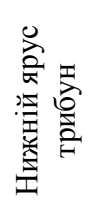 } & \multirow{3}{*}{ прохід у ряді крісел } & ширина проходу в ряді між кріслами, м & 0,4 \\
\hline & & & кількість людей у ряді, ос. & 18 \\
\hline & & & довжина евакуаційного маршруту, м & 10,5 \\
\hline & & \multirow{3}{*}{$\begin{array}{l}\text { радіальний прохід у секторі між ря- } \\
\text { дами крісел }\end{array}$} & ширина радіального проходу в секторі, м & 1,2 \\
\hline & & & кількість людей в потоці, ос. & 786 \\
\hline & & & довжина евакуаційного проходу, м & 5,5 \\
\hline
\end{tabular}

Практичне значення одержаних результатів. Апробація розроблених моделей і методів управління проектами БЕ СВС підтвердила їхню дієвість для підвищення рівня безпеки людей на спорудах цього типу в умовах виникнення НС. Зокрема на основі отриманих даних проведено оптимізацію часу реалізації проектів безпечної експлуатації стадіону "Арена Львів" у разі виникнення НС шляхом визначення оптимальних маршрутів руху зацікавлених сторін проектів, що представлені на споруді у вигляді план-схеми евакуації відвідувачів стадіону, а також запропоновано:

1. Встановити знаки навігації в секторах, на променаді, в адміністративній будівлі, на входах/виходах та інших ділянках СВС відповідно до розробленого маршруту руху потоків людей спорудою. Знаки навігації потрібно виконати відповідно до ДСТУ ISO 6309:2007. Розміщення знаків безпеки на території CBC допоможе відвідувачам обрати правильний евакуаційний шлях у випадку НС та збільшить швидкість їхнього руху. Для покращення візуальності знаків безпеки, їх доцільно зробити у збільшеному форматі, а в затемнених ділянках споруди здійснити освітлення.

2. Допоміжні перила на сходових клітках недоцільно встановлювати по всій довжині, оскільки вони розділятимуть людський потік на два незалежних потоки. У випадку, коли на одному 3 них щільність потоку буде надто високою i, відповідно, швидкість руху малою, а на іншому потоці ситуацію будемо спостерігати 3 точністю до навпаки, то люди не зможуть вільно перейти в потік із меншою щільністю. Тому пропонуємо не встановлювати, а у випадку, коли вже встановлені - демонтувати допоміжні перила на площадках сходових маршрутів, з метою можливого перерозподілу людей в потоках, що підвищить швидкість їхнього руху та ефективність використання евакуаційних виходів.

3. Встановити стюардів для загального регулювання руху людських потоків по СВС, а також на ділянках, які $\epsilon$ "вузькими" місцями, з метою уникнення скупчень людей, що призводять до затримки руху.

4. Трибуни другого ярусу, відповідно до проекту, мають ухил $37^{\circ}$, що передбачає використання огороджувальних систем. Такі системи на стадіоні "Арена Львів" виконано як допоміжні перила на краях радіального проходу в секторі, що створюють, за неправильного їх влаштування, додатковий бар'єр на евакуаційному шляху при виході з бічного проходу. Оскільки такі огороджувальні системи виконано відповідно до чинних норм ДБН і є додатковими елементами безпеки глядачів, то при виході 3 рядів огородження не повинні зменшувати прохід менше ніж на 35 см. В іншому випадку, зменшується швидкість виходу людей із рядів та порушується одна 3 головних умов - забезпечення безперешкодної евакуації людей.

5. 3 метою рівномірного розподілення потоків людей по CBC та створення можливості для швидкого отримання інформації для визначення оптимального евакуаційного маршруту, доцільно на одній із сторін запрошення (пропускного квитка) на культурний чи спортивно-масовий захід навести схематично евакуаційний маршрут із зазначеного в запрошенні глядацького місця.

Висновки. За результатами проведеного дослідження можна зробити такі висновки:

1) інформаційний аналіз реалізації проектів побудови об'єктів масового перебування людей показав, що найкращим способом убезпечення $\epsilon$ проведення своєчасної евакуації людей, що виступають у ролі зацікавлених сторін проекту, у безпечну зону;

2) у випадку вживання міжнародних масових заходів на спортивно-видовищних спорудах необхідно узгодити нормативно-правові бази України та світу у питанні убезпечення людей;

3) на основі запропонованої у роботі вдосконаленої методики розрахунку тривалості евакуації людей із споруд проведено обчислення стосовно визначення тривалості евакуації людей із стадіону "Арена Львів".

\section{Перелік використаних джерел}

Bushuiev, S. D. (2010). Kreatyvni tekhnolohii upravlinnia proektamy ta prohramamy. Kiev: Samyt-Knyha. [In Ukrainian].

Chernov, S. K. (2006). Systema ryskov v orhanyzatsionnykh proektakh. Zbirnyk naukovykh prats Natsionalnoho universytetu korablbuduvannia, 2, 163-168. [In Ukrainian].

DBN V 2.2-13-2003. (2004). Budynky i sporudy. Sportyvni ta fizkulturno-ozdorovchi sporudy, from 01 Mart 2004. Kiev, 101 p. [In Ukrainian].

DBN V 2.2-9-09. (2010). Budynky i sporudy. Hromadski budynky $i$ sporudy, from $01 \mathrm{Jul} 2010$. Kiev, 51 p. [In Ukrainian].

Football Association. (1991). The control of crowds at football matches. London, $297 \mathrm{p}$

Holshevnikov, V. V., \& Samoshyn, D. A. (2009). Academy GPS MCHS of Russia, $212 \mathrm{p}$.

HOST 12.1.004-91. (1991). Pozharnaia bezopasnost. Obshchye trebovanyia. Retrieved from: http://document.ua/ssbt.-pozharnajabezopasnost.-obshie-trebovanija-nor3057.html. [In Russian]. 
Ivanusa, A. (2018). Project of forming "culture and safety" of the airport. MATEC Web of Conferences, 247, 00045.

Ivanusa, A. I., \& Rak, Yu. P. (2013). Pidkhody upravlinnia proektom bezpechnoi evakuatsii liudei na stadionakh $\mathrm{v}$ umovakh nadzvychainykh sytuatsii. Skhidno-Yevropeiskyi zhurnal peredovykh tekhnolohii, 145-147. [In Ukrainian].

Nakaz MNS Ukrainy. (2012). Pro zatverdzhennia Pravyl pozhezhnoi bezpeky dlia sportyvnykh budynkiv ta sporud vid 08.10.2012 r., № 1243. Retrieved from: http://zakon4.rada.gov.ua/laws/show/z180312. [In Ukrainian].

Rach, V. A., Rossoshanska, O. V., \& Medvedieva, O. M. (2010). Upravlinnia proektamy: praktychni aspekty realizatsii stratehii rehionalnoho rozvytku. Luhansk. [In Ukrainian].

Situat. of Russia. (2009). Order of the Min. of Emerg. Situat. of Russia.
Sports Grounds. (1997). Guide to Safety at Sports Grounds. Retrieved from: $\quad \underline{\text { https://www.raithrovers.net/files/GuidetoSafetyatSports }}$ Grounds.pdf

UEFA. (2006). Stadium Infrastructure Regulations. Edition, 15 p.

Yemelyanenko, S., Ivanusa, A., \& Klym, H. (2017). Mechanism of $f i-$ re risk management in projects of safe operation of place for assemblage of people. CSIT, 1.

Zachko, O., Golovatyi, R., \& Yevdokymova, A. (2017). Development of a simulation model of safety management in the projects for creating sites with mass gathering of people. Eastern-European Journal of Enterprise Technologies, 2, 3(86), 15-24.

Zakon Ukrainy. (2011). Pro osoblyvosti zabezpechennia hromadskoho poriadku ta hromadskoi bezpeky u zviazku z pidhotovkoiu ta provedenniam futbolnykh matchiv vid 07.08.2011 r., № 3673-VI. Retrieved from: http://zakon4.rada.gov.ua/laws/show/3673-17. [In Ukrainian].

A. I. Ivanusa', R. S. Yakovchuk1, S. O. Yemelyanenko', Z. Z. Ivanusa ${ }^{2}$

${ }^{1}$ Lviv State University of Life Safety, Lviv, Ukraine

${ }^{2}$ Lviv State University of Internal Affairs, Lviv, Ukraine

\section{SOME MANAGEMENT AND INFORMATION ASPECTS OF THE PROJECT OF SAFETY OPERATION OF SPORTS AND ENTERTAINMENT BUILDINGS}

The analysis of the successful practices for implementation safety evacuation from public gathering places showed that the main way to ensure the safety of people at sports and entertainment buildings is to create the conditions for timely and unobstructed people evacuation to a safe zone. The evacuation process from sports and entertainment buildings, in accordance with international requirements should not exceed 8 minutes. As a result of the analysis, we found the following issues: constant improvement safety and comfort level of sports and entertainment buildings in the organization of any measures of international importance requires implementation of the projects for the construction of new or reconstruction of old sports and entertainment buildings; there is a discrepancy between the requirements of current Ukrainian legislation and the world in terms of ensuring human security; high cost of projects implementation for safety operation of sports and entertainment buildings due to the uniqueness of their construction; there is no legal framework and Rules of Conduct that would determine the order of implementation of projects in the field of ensuring the safety of people at their mass facilities; it is advisable to use project management in the implementation of projects for the safe operation of sports and entertainment buildings. As a result of the research, theoretical bases were developed, based on the topological analysis and synthesis of systems for managing the flow of people, which are the stakeholders of projects for the safe operation of sports and entertainment buildings. The tools for implementing such projects are based on the formalization of methods and models that inform the state of their current implementation. A conceptual model of project management of the safe operation of sports and entertainment buildings has been developed, which result is the life and health of the project stakeholders. It was also found that for the calculation of the time of evacuation of the stakeholders of safe operation projects of sports and entertainment facilities from the boardwalk sectors, the most optimal is to use an analytical model that takes into account the topology of movement of the human flow, and from the boardwalk to the safe zone - models of individual-flow movement the composition of the stream, which is shown as a modified Erlang function.

Keywords: sports and entertainment buildings; life safety; evacuation of people; safety-focused project management. 